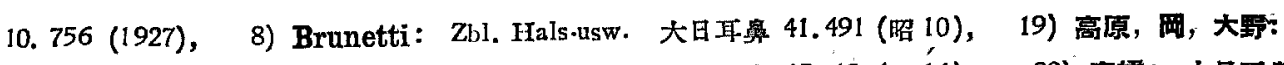

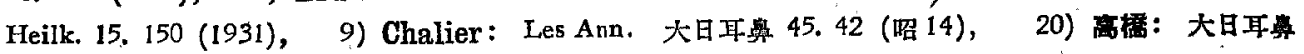

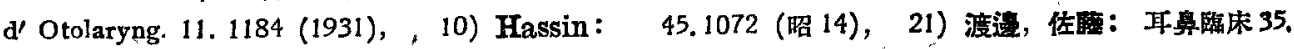
Archive Neur. \& Psych. 29.359 (1933)，11) Ru- 937 (昭 15)，22) 田中：日本耳鼻全夆 3,3 ttin: Acta Otolaryng. 19.66. (1934), 12) Ni-, elsen: Ann. of Otology etc. 46.13 (1937), 13) Cullen Ward Irish: Ann. of Qtology etc. 47. 78 \& 402 (1938), 14) 田中, 案原, 西村：大日 耳用 38.599 (昭 7)，15）今井：大日耳學 38 . 625 (昭7)，16）田中：臨林医学 8. (昭 8),

17) 小山：大日耳畐 39.762 (昭 8 )， 18) 撟本:

病理学数室三宅化教授及び当敉室主任切替 数授の御校閱を感謝す。

（原稿到着二昭和 23.7.12）

- HIDETSUGU KATO, M D.: ON THE INFLUENCE ON THE BODY BALANCING ABILITY EXERTED BY CAIONIC EXCITATION OF THE EXTERNAL EAR CANAL

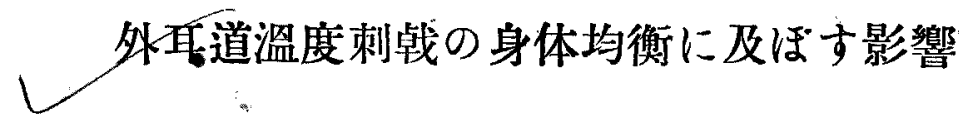

京都帝國大学医学部耳悬咽喉科教等（指酎 星野敉授）

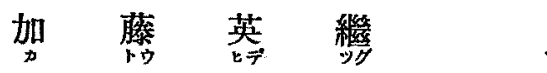

身体の均衡は各揫感覚器の官能が夫々協調登 動せられることによつて維持せられ，就中前

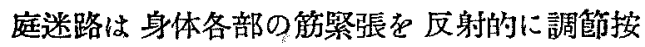
配することによつて身体均衡に大いに関與し てるる。即ち前庭迷路は左右相效的に存在し。 両者相俣つて一なる作用, 均衡心関與し, 從 つ一側迷路の機能廃絕皌至低下は左右迷路 に官能的差基を生し，之が身体均衡に影響灰 與えるものと理解される。而して一側迷路の 噟圆，或は機能廃絕が均衡機能に重大な影蚃 を留すことは既に明かなる事実であるが，斯

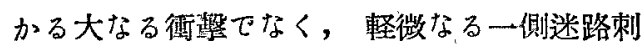
战により，左右迷路の微絸なる官能的善翼を 惹起せしぬたる場合には，果して身体均衡に 影響を與うるものであるうか。本間題に付き
余は一側外耳道に徽弱なる温度刺战を與えた る後，單脚值立檢查を実施し，下記の成續 を得たので其概略る述へる。

\section{實驗材料並に實驗方法}

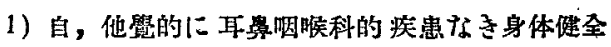

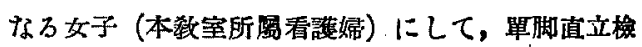
查に於いて兩脚共 30 秒以上安定に直立し得万6の 10 名尼選定し被检者とした。

2) 閉眼一侧耳注大蛽醶

被检者の外耳道を清渭したる後，一側耳每に夫之 $27^{\circ} \mathrm{C}$ 水 $1 \mathrm{cc}, 44^{\circ} \mathrm{C}$ の水 $1 \mathrm{cc}, 37^{\circ} \mathrm{C}$ 水 $1 \mathrm{cc}$ 外开道に約 3 移の速度を以て注大し，各水注大直挠 より 60 秒に至万間，眼球尼梚察したる後，闒眼に

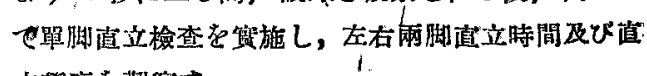

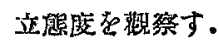


3) 閉眼雨側耳注入蝶噞

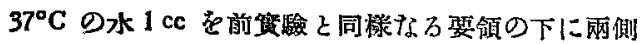
外耳道に同時に注入したる啳，闒眼單脚㨁立检查を

\section{寅施寸。}

4) 開眼一側外耳道注入算驗

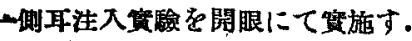

\section{霓 驗成綪}

1)，一側外耳道 $27^{\circ} \mathrm{C}, 44^{\circ} \mathrm{C}, 37^{\circ} \mathrm{C}$ 宁各 液 $1 \mathrm{cc}$ 注入後の單脚直立成績（閉眼）.

\begin{tabular}{|c|c|c|c|}
\hline \multirow{2}{*}{ 溫度别 } & 注入前の成績 & \multicolumn{2}{|c|}{ 注大後の成績 } \\
\hline & 值立特間| & 㨁立時間 平均値 & 䈍 \\
\hline $27^{\circ} \mathrm{C}$ & $30 \mathrm{n}$ 以上定 & $3,4^{\prime \prime}$ & \begin{tabular}{|l} 
丕定洼入 \\
洼入
\end{tabular} \\
\hline $10 \mathrm{C}$ & 30 / 以上安定 & $13,5^{\prime \prime}$ & \\
\hline $7^{\circ} \mathrm{C}$ & $0 /$ 以上安 & 30" 以上 & 安定 \\
\hline
\end{tabular}

2) 両側外耳道各液 $1 \mathrm{cc}$ 同時 注入後の單 (脚直立成績（閉眼）

\begin{tabular}{|c|c|c|c|c|}
\hline \multirow{2}{*}{ 㴧度別 } & \multicolumn{2}{|c|}{ 注入前の成績 } & \multicolumn{2}{|c|}{ 注大後 $の$ 成續 } \\
\hline & 直立時閒 & 䈍度 & $\begin{array}{l}\text { 直咅時閒平 } \\
\text { 均值 }\end{array}$ & 態 度 \\
\hline $27^{\circ} \mathrm{C}$ & 30" 以上 & 安定 & $19^{\prime \prime}$ & 稍安定 \\
\hline $44^{\circ} \mathrm{C}$ & $30^{\prime \prime}$ 以上 & 安定 & $2 I^{\prime \prime}$ & 䅌安定 \\
\hline
\end{tabular}

3) 一側外耳道各液 $1 \mathrm{cc}$ 注入後の 開眼單脚 直立成績

\begin{tabular}{|c|c|c|c|c|c|}
\hline \multirow{2}{*}{ 搵度别 } & \multicolumn{2}{|c|}{ 注入前の成績 } & \multicolumn{3}{|c|}{ 注入後の成績 } \\
\hline & 直安時閒 & 態苳 & 直立時本均値 & 䁌 & 度 \\
\hline 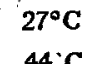 & 30 以上 & 安定 & 30" 以上 & 安 & 定 \\
\hline $44^{\circ} \mathrm{C}$ & 30" 以上 & 安定 & $30^{\prime \prime}$ 以上 & 安 & 定 \\
\hline
\end{tabular}

\section{態度の制定}

1）安定一身体動播することなく直立姿勢を 維持する場合

2）稍安定一上体亚に下肢か;軽度に動搖する

3) 不安定一上体，上陸か强く動摇し，直 立脚足跎位置が移動する場合

\section{樬括並に考按}

1）促康人 10 名に就きて外耳道に夫な 27 ${ }^{\circ} \mathrm{C}, 44^{\circ} \mathrm{C}, 37^{\circ} \mathrm{C}$ の各温度の水 $1 \mathrm{cc}$ 一側 或は両側に注入したる後，閉眼亚に開眼にて 單脚直立檢查老実施す

2）各温度の水注入直挠より 60 秒に至る閒 に於て眼球偏倚並に眼震は闪眼的䃆察方法に ては其発現を確認し得す。

3) $27^{\circ} \mathrm{C}$ 並に $44^{\circ} \mathrm{C}$ の水を一側外耳道に注 入後の閉眼單脚直立に於いては，值立洔間は

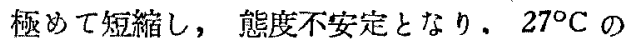

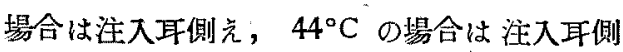
反対側光顛倒せんとする傾向を示す

4) $37^{\circ} \mathrm{C}$ の水注入の場合の閉眼單脚直立に 於いては直立时間並に態度は 注入前のそれと 殆ど変化を認めない。

5）両側外耳道同時注入の場合は直立時間は 稍短縮吉る。

6）開眼單告直立成績は一側耳注入の場合に 於いても注入前の成綪と略々同核である。

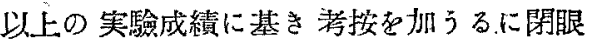
單脚直立に於いて $37^{\circ} \mathrm{C}$ の体温と略闰梯なる 水注入の場合には，注入前單脚直立姿勢に変

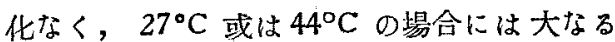
変化を示すことは，外耳道壁及び鼓膜の液体 注入に上る液体の接触即機㭜的刺㦸のみにて

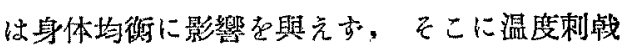
が版つな場合は其微量に於いても相当大なる 均衡破綻を招來することを認め得たのである。

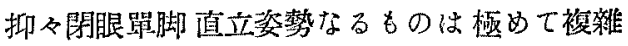
なる機制の下に維持される生理現像であるが， 前庭迷路も亦重大なる意味をるって之に関與 してるることは疑いのない事実であるから， 斯方る微弱なる温度刺械が同倒の前庭迷路を 刺战興整することは理解出來るのである。

而して外耳道刺战が一侧のみの刺战よりる 両側同時刺战の場合が其均衡破䑸の程度加軽 微なる事実は，両侧迷路は両々相俣つて一な 
る作用，身体均衡を司り，両側迷路の官能 问程度なる場合に均衡えの両者協動作用は最 高度に発䶝され，左右の官能的差異を生じた 場合には，其差異が極めて微細なる程度なる 場合に於心て 路廃絕の場合の如く，其美異高度なる場合に は均衡も亦最高度に破綻するものと考光られ る.

次に閒眼 單踋直立に於いて 斯汃る大なる均 衡破綻を惹起するにも拘らす，開眼直立に於 いては始ど均衡將態に変化者示さない事実は， 視觉の均衡機能えの関與が强大なることを示 㖫するのである。換言すれば視覚は或程度ま で均衡破綻を補正し得るのである。從つて此 事加ら均衡障碍を視覚による裐正筙囲內にあ
るものと筑囲外にあるるのとに大別し得る事 が出來，本観察の如き程度の温度刺戱による 均衡破淀は前者に属するものと言えよう。

要之，外耳道温度刺㦸は，本観察に於け るが如く通常の 肉腿的観察方法に拪りては眼 震丈は眼球偏倚を確認せさる程度の微細量に 於いても，比较的大なる均衡破綻を爽し， 斯加る均衡破綻をも視喾によって 知正し得る そとを逨べたのである。

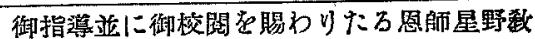

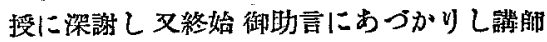
末席, 吉川爾博士に多謝する。

（原稿到荒＝绍和 23.7.18）

HIDETSUGU KATO, M.D. AND FUKASHI KATAYAMA, M.D.: ON THE SIGNIFICANCE OF THE PREPARATORY WALKING IN THE WALK TEST

\section{し步行檢查に於ける準備步行の意義に就て}

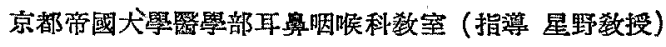

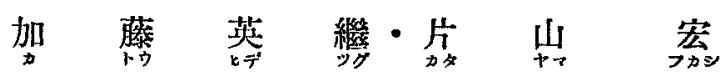

身体の本衡は各種の感覚器の官能が夫々協 調発動せられることによつて維持せられてる るか、其中でも重娶な役割を果してるるのは

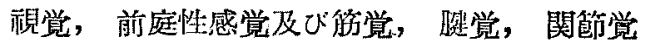
等を含む所の所謂深部感覚である。そして之 等の感営が相互に共働的に作動して頭位並に 体位に関する刺战，即ち大地に対する位置指 南に役立つ刺㦸を中枢に呈供する，從つて之 等の感営が 意瞕領域に上らないまでも"其機能 が棹密に働き, 且之等の器官の感受した刺战 を袖経衝整として正確に求心集達せられるこ とにより甫めて身体の本衡か碓約せられる。
視覚の 身体平衡維持に対する役割は極めて 重大であることは一旦悓覚を奪うならば身体 の位置に関する指南は忽ち不正確となり，直 進運動の如きる全く不確実になると云うこと に依りても容易に理解せられる。即ち遾眼の 狀態にて值進運動を行う場合，其運動は旋伵 運動となり，其足蹠移動の軦跡は略々一定の

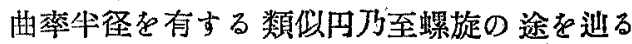
のである。此事は既に普く知られてるる事赛 であって，步行に際しても，游泳に於てす 常に観られる現象である。

斯くの如く吾人の視喾が嚄われた場合，其 
ren under 10. The preceding otitis is mostly on the right side and oftener of the acute nature.

In both of the present cases, the sculp developed the edematous, painful swelling, i. e. Gradanigo's symptom. This can be regarded as the sole symptom peculiar to this disease, though it may not always occur, being on record in 8 cases among 45 .

Intra-cranial syndrom, observed in many cases indeed, is not, however, characteristic exclusively of this disease, being common to the intra-cranial circulatory disturbance cerebral edema, hemorrhage or abscess, and secondary softening, etc.

(Abstract)

ON THE INFLUENCE ON THE BODY BALANCING ABITITY EXERTED BY CALONIC EXCITATION OF THE EXTERNAL EAR CANAL.

\author{
- by \\ HIDETSUGU KATO
}

From the Oto-Rhino-Laryngological Clinic (Prof. T. Hoshino),

Medical School, University of Kyoto.

Body balancing ability as tested by means of the "one-legstanding" was proved to be definitely affected rather strongly by moderate caloric excitation applied to the meatus of one side, though it was so moderate as ineffective to cause the nystagmus or ocular deviation.

(Abstract)

\title{
ON THE SIGNIFICANCE OF THE PREPARATORY WALKING IN THE WALK TEST
}

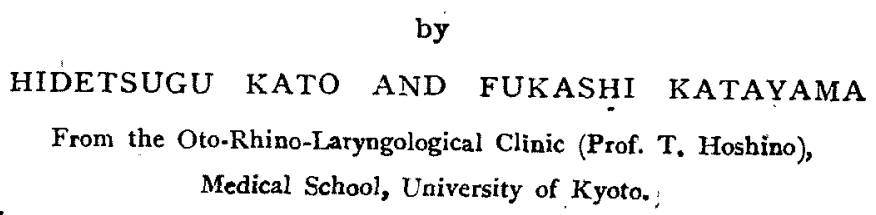

In testing the body-balancing ability by means of the walk test, the anthors tried a modification in applying preparatory walking, with eyes open, over a length of 1.5 m. This modification proved to give more reliable results than the original walk test without the preparatory walking.

(Abstract) 